\title{
The Model of Mobile Application-Based Learning in Social Sciences Learning to Enhance Students`Digital Literacy
}

\author{
Aim Abdulkarim ${ }^{1, *}$, Neiny Ratmaningsih ${ }^{2}$, Diana Noor Anggraini ${ }^{3}$, Pitria \\ Sopianingsih ${ }^{4}$
}

\author{
1,4 Dep. of Civic Education, Faculty of Social Sciences Education, Universitas Pendidikan Indonesia, Bandung, \\ Indonesia \\ ${ }^{2,3}$ Dep. of Social Sciences Education, Faculty of Social Sciences Education, Universitas Pendidikan Indonesia, \\ Bandung, Indonesia \\ "Corresponding author.Email: aimabdulkarim@upi.edu
}

\begin{abstract}
In education 4.0 dynamically required to create media, method, and educational material that is increasing digital literacy. The adaptation of digital literacy movement can be integrated with curriculum and the digital learning system. So that, we have to develop mobile application-based learning model which is very potential to enhance students' digital literacy. A Research and Development approach was employed. Data were gathered through questionnaires, observations, and focus group discussions. Quantitative and qualitative data were collected and analyzed separately. The subjects were students, lecturer, and experts in Bandung, Indonesia. The results of research: 1) research development was through five stages: analysis, design, development, implementation and evaluation; 2) product designed application was "Edsodia" with the goal of educating students in the use of social media wisely. The content of application, such as: profile, social news, articles, videos, images, forums, explore; 3) results of the validation of media and material experts shows a score of $80.33 \%$ and $89.73 \%$. Based on a category level validation, can be interpreted that the mobile applications in social sciences learning very good use. Authors hope that this viewpoint can provide some new ideas for development of media innovative on 21 th century social learning in universities.
\end{abstract}

Keywords: digital literacy, mobile application, social sciences learning, students.

\section{INTRODUCTION}

Nowadays, society has transformed into information society through the demand of technology in Industry 4.0. The characteristic of Industry 4.0's society is its massive dependency on Information Technology. Rapid advances of technology enable automation in most of every fields. Technology and its recent approach that fundamentally integrate physical, digital, and biological world will definitely transform the lifestyle and interaction of human being [1].

This fact is an advantageous opportunity for education experts who keep moving dynamically, especially in creating media, methods, and educational materials that are getting more and more interactive and comprehensive. The customarily available media are books, magazines, journals, newspapers, and tabloids for offline media, radio, TV, and also internet as online media [2], [3]. That the development of technology in education had shifted lecturing method towards the use of learning media. The media itself are constantly developing; from printed in the form of books until audio-visual ones that are shown through the internet.

Digital learning is the system that should be developed in Industry 4.0. [4]. States that utilizing technology gives a significant impact towards learning. This is in line with the fact that the utilization of mobile devices (smartphone, PDA, or tablet) is no stranger to students. Technology that has a role in learning process will influence the conception of curriculum through three ways, namely: 1) the utilization of recent technology as the social purpose of the curriculum, 2) technology provides the resources for the curriculum development as it enables teachers to find and gather teaching materials and also guides students in learning, 3) technology can provide the assessment tools for practical fields such as simulation [5]. All those three benefits of Information 
and Communications Technology (ICT) are impactful towards education development.

The use of mobile devices in learning process then known as mobile learning (m-learning) [6]. Androidbased mobile learning media are the alternatives that have unique characteristics such as mobility (accessible anywhere, anytime) as well as the attractive visualization. However, the fact shows that m-learning has not been commonly utilized for learning in educational purpose. The challenge lies in the unavailability of mobile-based learning contents that are widely accessible. Most of the available contents in the market are dominated by entertainment which lacking in educational aspects. This fact brings up the needs of greater, various, affordable, and accessible android-based contents/apps [7].

Referring to the previous opinion, authors assume that in order to develop digital learning that can increase students' digital literacy, the development of mobile application-based social sciences learning which arranged and designed during lectures is required. Particularly, the problem is elaborated into these questions:

1. How to design (needs analysis, product design, product development) mobile application-based social sciences learning?

2. How is the implementation (method, process, interaction, evaluation) of mobile application-based social sciences learning?

3. How to validate the feasibility of mobile application-based social sciences learning?

\section{THEORETICAL REVIEW}

\subsection{Social Science Learning}

Social Science learning can be defined as a system or process of teaching Social Science students/learners that are planned or designed, implemented, and evaluated systematically so that students/learners can achieve Social Science learning objectives effectively and efficiently [8]. Learning and Learning Social Sciences are two activities that cannot be separated from each other. The relationship between learning and learning in Social Sciences can be described in a system, the learning and learning process in Social Sciences requires basic input (raw input) which is a learning experience material in the learning teaching process (learning teaching process) with the hope of turning it into output with certain competencies. In addition, the learning and learning process of Social Sciences is also influenced by environmental factors which become environmental inputs and instrumental factors (instrumental inputs) which are factors that are deliberately designed to support the teaching and learning process and the outputs to be produced. [8].

\subsection{Learning Media}

The word media comes from Latin, namely the plural of the word "medium" which literally means intermediary or introduction. Medium can be defined as an intermediary or introduction to the occurrence of communication from the sender to the receiver [9], [10].[11]. Media is one component of communication, namely as a messenger from the communicator to the communicant Media is also an intermediary or messenger from the sender to the recipient of the message [12].

Learning is an effort to teach students. From the description above, if we combine the two concepts, it will become a learning medium that can be concluded as something that the teacher uses to convey messages in the form of learning materials to students which are intended so that students can receive material effectively. Learning media always consists of two important elements, namely elements of equipment or hardware (hardware) and elements of the message it carries (message/software) [13]. Suggest four functions of learning media, especially visual media, namely (a) attention function, (b) affective function, (c) cognitive function, and (d) compensatory function.

\subsection{Application}

Application (application) is software created by a computer company to do certain tasks, such as Microsoft Word, Microsoft Excel [14]. Another understanding explains the application is the application, use or addition. According to Huda application components are an important part of an Android. Each component has a different function, and the components are interconnected with each other. the application components that must be known according namely: (1) Activity; (2) Services; (3) Intense; (4) Content Providers; and (5) Resources. [15].

\subsection{Mobile Learning}

Mobile learning or abbreviated as m-learning is a learning technology using a mobile device that allows a person (student) to access information and learning materials anytime and anywhere that occurs when students utilize mobile technology devices. [16], [17]. Mobile learning or M-Learning offers a modern way to support the learning process through mobile devices such as tablets, smartphones and cell phones [18]. Mobile learning has a fairly close relationship with e-learning. Basically, mobile learning is a development of the concept of e-learning. E-learning itself is part of distance learning (distance learning) so, mobile learning is also part of distance learning [6]. learning is part of eLearning, so there are 2 types of division of this learning method according namely Synchronous training and Asynchronous training. Every development of a mobile learning system always consists of three main domains, namely mobile usability, wireless technology, and elearning system [19].

\subsection{Social Media}

Social media as a medium "...which enables the creation and exchange of user-generated content". This means that all media used to support exchange between 
people, such as e-mail, wikis, blogs, and so on, are content and forums that can be used as social media [20]. Most social media increase interactions between people, which is often said to have a positive impact on learning outcomes in higher education Horton states that when we examine the definition of social media, the following criteria emerge: 1) Internet-based; 2) Users generate and publish information; 3) Community sharing posts, comments, data, even hobbies; 4) Multimedia; 5) Can directly publish; f) Eliminating geographic barriers; 7) Incorporating old and new internet technologies.

\subsection{Digital Literacy Ability}

Literacy also means practices and social relations related to knowledge, language, and culture [21]. Digital literacy is aimed at improving the ability to read, analyze, and use information in the digital world (Big Data), technological literacy aims to provide an understanding of how machines work and technology applications, and human literacy is directed at improving communication skills and mastery of design science [22]. According to Trillling and Fadel, 21st century learning is oriented towards digital lifestyles, thinking tools, learning research and how knowledge works. The content of $21 \mathrm{st}$ century learning must always adapt to changes, including in the industrial era 4.0. The learning content is expected to be able to fulfill 21 st century skills; 1) learning and innovation skills include mastery of diverse knowledge and skills, learning and innovation, critical thinking and problem solving, communication and collaboration, and creativity and innovation, 2) digital literacy skills including information literacy, media literacy, and ICT literacy, 3) career and life skills include flexibility and adaptability, initiative, social and cultural interaction, productivity and accountability, and leadership and responsibility [23].

\section{METHODS}

This research is done through Research and Development (R\&D) approach. According to Borg \& Gall [24]. R\&D model is a process used to develop and validate educational product. It means that this $R \& D$ in education is a process which used to develop and validate the product of education. This research also called 'research-based development', which comes as a strategy to increase the quality and productivity of education by creating a product. The products of education can be in the form of curriculum, learning methods, learning media, textbooks, models, evaluation system, etc.

The instruments used for data collection are as follow; 1) questionnaire; 2) interview protocol; 3) Fieldnotes, and 4) Focus Group Discussion (FGD) protocol. The qualitative data analysis is conducted through: (1) data reduction by summarizing fieldnotes, highlighting the main points that are relevant with the focus of the research; (2) systematically arranging data based on particular category and classification; (3) displaying data through tables or pictures so that the relationship between data becomes clear and intact; (4) conducting cross site analysis by comparing and analyzing data in depth; and (5) presenting findings, drawing conclusion in form of common tendency and its implications, also recommendations for development [25].

This data analysis procedure begins with analyzing the result of students' researches within the last three years, analyzing the result of in-depth interview and the minutes of meeting of the focus group discussion. Then, data triangulation is conducted to verify and confirm the validity. After that, data analysis in form of presentation, diagram, mapping pattern of basic competence, also the alternative of problem solving which is concluded as findings and recommendation towards the result of the research is conducted. Qualitative analysis conducted for data that are collected through questionnaire, using rating scale which results are in the form of percentage [26]. They are variables. Equations should be either display (with a number in parentheses) or inline. Use the built-in Equation Editor or Math Type to insert complex equations.

\section{RESULTS AND DISCUSSION}

This research and development of mobile applicationbased social sciences learning is an adaptation of ADDIE development model which covers five phases: analysis, design, development, evaluation, and implementation.

\subsection{Design Phase}

Design phase of the product is drawn through a storyboard. Within such condition, the help from storyboard is needed to give clarity on the job for each designer that is included in a team. Synchronization still is required for one application designer to make sure that the result of each page of the application stay in uniform. Picture 1 shows the visual design of storyboard on the main page similar to social media by signing in through facebook, google, twitter, or email.

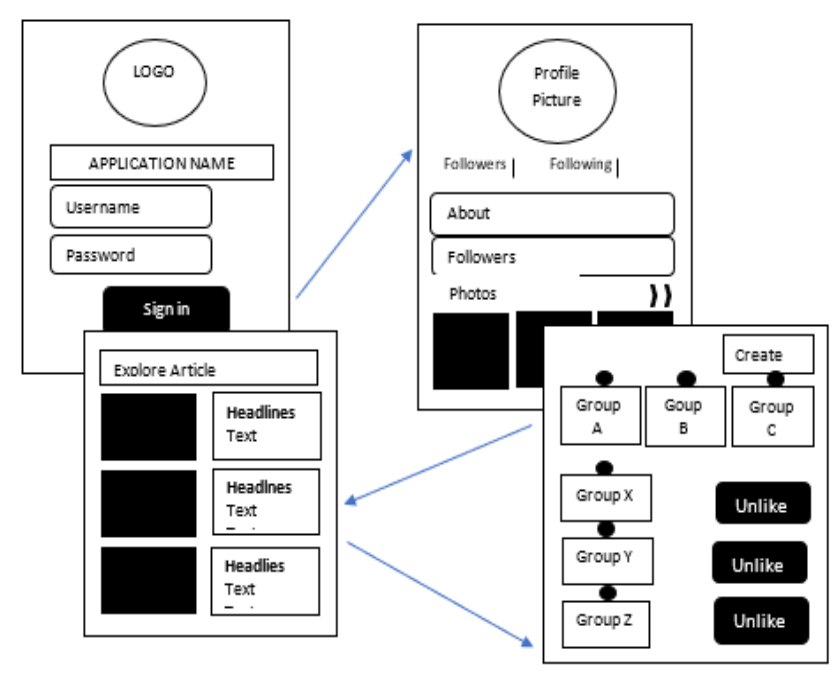

Figure 1. Visual Design of Storyboard Menu 


\subsection{Development Phase}

In development phase, data collection instruments and learning devices instruments are arranged and validated. The instruments for data collections are questionnaire of students' responses toward learning media, pre-test and post-test of learning outcome, and pre-test and post-test of digital literacy. The application starts from signing in through other social media accounts, developer's name and the application version. On the homepage of application, there are options (menu) for each of these pages:

\section{a. Login page}

Login page is meant for accessing the system with personal account to make sure that each user has an ownership of his/her own. At the start of access, users have to $\log$ in with either created account or any existing account of social media such as Facebook, twitter, Gmail, etc.

\section{b. Feature page}

This page provides some features that can be used by users. The list of the features consists of my profile, messages, contacts, saved posts, groups, pages, blogs, marketplace, events, find friends, and movies. All of those features are free to use to support users' needs in communication.

\section{c. Profile page}

This page contains the ownership identity of the account. Users can upload photos and fill in the 'about' description to describe personal identity. Besides users can discover the people that are included in the list of followed, following, and likes.

\section{d. Article and blog page}

Users can create their own article and blog or just viewing those which others' have made. They can also upload photo for their article and blog or simply just giving likes and comments to others'.

\section{e. Forum page}

Forum or group page can be made by each user to communicate within community. The forum and group can be used to share and discuss some social phenomenon or just to get to know each other. Within a group, user should start a topic beforehand so that the communication will be guided according to the topic.

\section{f. Posting page}

This page can also be made by each user. Each account can post status message or statements which content will certainly be limited by the Edsodia security. This shows Edsodia's stance to disprove any contents that are inappropriate according to Indonesian culture characteristics.

\subsection{Implementation Phase}

During the implementation phase, learning media is being tested to students as the users of Edsodia application that has been developed. This testing is aimed to discover how is the use of the application, their responses after using the application, also to reveal how students would assess it. The implementation is done in public and private universities in Bandung, West Java. The organized mobile application-based learning is integrated within Social Sciences Education lectures through these steps:

a. Internalization of Digital Literacy in Course Learning Outcomes

Course introduction, Syllabi (RPS) and Lesson Plans (SAP) briefing, continued with building commitment in realizing the social class through internalization of digital literacy in course learning outcomes. After the learning outcomes for the Contemporary Social Issue course are formulated, then the scope of discussion is approved according to the syllabus.

b. Making Groups and Assigning Social Experiment through social media

Students are divided into 10 groups by democracy with these agreements: (a) Each group specifically identify the social problem; (b) The main problem is made as reference for inquiry/data finding process in form of photo, video, graphic, and writing; (c) Each group compose a news-based writing that prioritize facts, data, and theories until it can be uploaded into social media.

\section{c. Giving Online Assignments and Quizzes}

Lectures can't be separated from assignments and any other evaluation tools. Mobile application-based social sciences learning emphasizes the online learning process. Students can work on the online program anywhere and anytime. The assignments are uploaded by lecturers periodically according to the previous lecture material. Other than that, quiz can be made as an additional assessment tool to measure how far the students can understand about a social problem through multiple choices items and also pictures, videos, lyrics, or story analysis.

\section{d. Building Online Forum Connectivity}

The discussion forum available in Edsodia considers the multi-way communications so that the group communication understanding can be achieved early. Online forum discussion can be started by lecturers or students themselves so that later they will respond to each other and able to give solutions.

e. Digital Literacy Attitudes in Social Sciences Education Lectures

At the end of the lectures, lecturer would review the material (data, facts, concept, principle, procedure) and 
also explore, clarify, reflect, internalizing, and motivating the students to be together in sustainably applying digital literacy in family, college and society life.

\subsection{Validation of Mobile Application as a Learning Media}

This validation phase is conducted to test the feasibility of the developed application. This phase involves media expert and material expert. The test by the media expert is seen from the manipulation of software and visual communication while the test by material expert is seen from the learning aspect. The media feasibility test is conducted by an expert in multimedia. The tested aspects are communication, computer/android capacity, creativity, appropriateness, visual design, and interactivity. The result of the multimedia feasibility test is described through this table:

Table 1. Processing of the Media Expert Validation Result

\begin{tabular}{|c|c|c|c|c|c|}
\hline $\begin{array}{l}\text { Sub } \\
\text { Variable }\end{array}$ & $\begin{array}{l}\mathrm{N} \text { of } \\
\text { Ite } \\
\mathrm{ms}\end{array}$ & $\begin{array}{l}\mathrm{N} \text { of } \\
\text { Exam } \\
\text { iner }\end{array}$ & $\begin{array}{l}\text { Criter } \\
\text { ium } \\
\text { Score }\end{array}$ & $\begin{array}{l}\text { Gain } \\
\text { Score }\end{array}$ & $\%$ \\
\hline $\begin{array}{l}\text { Communic } \\
\text { ation }\end{array}$ & 3 & 1 & 15 & 13 & 86,66 \\
\hline $\begin{array}{l}\text { Android } \\
\text { Capacity }\end{array}$ & 2 & 1 & 10 & 8 & 80,00 \\
\hline Creativity & 5 & 1 & 25 & 22 & 88,00 \\
\hline $\begin{array}{l}\text { Appropriat } \\
\text { eness }\end{array}$ & 3 & 1 & 15 & 11 & 73,33 \\
\hline $\begin{array}{l}\text { Visual } \\
\text { Design }\end{array}$ & 2 & 1 & 10 & 8 & 80,00 \\
\hline $\begin{array}{l}\text { Interactivit } \\
\mathrm{y}\end{array}$ & 3 & 1 & 15 & 12 & 80,00 \\
\hline
\end{tabular}

Average

80,33

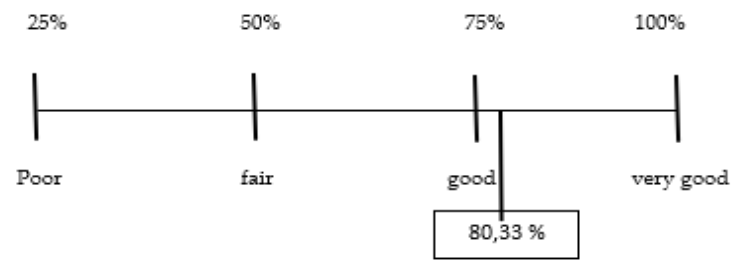

Figure 2. Media Expert Rating Scale
Media expert validation can be seen in Table 1 which shows that the application communication aspect is valued very good with $86,66 \%$ of percentage score, computer capacity aspect is valued very good with $80,00 \%$, creativity aspect is also valued very good with $88,00 \%$, appropriateness aspect is valued good with $73,33 \%$, meanwhile the visual design scored $80,00 \%$ which is a very good value. All the scores resulted in $80,33 \%$ average. Based on validation level category of the score results, it can be interpreted that Edsodia is very good to be utilized in learning.

Based on the empirical findings that shows positive and significant effect of the implementation of mobile application-based learning towards the development of students' digital literacy, the results provide this following information:

First, this research and development of mobile application-based learning is conducted with ADDIE development model adaptation which covers five phases, namely: analysis, design, development, implementation, and evaluation. Each mobile learning development always consists of three primary domain that are mobile usability, wireless technology, and e-learning system [19]. Research leads to applying mobile skills to the internet as a resource for learning and concerned with the management of information in academic and professional practice. Out of this have come competence frameworks and other means of regulating and assessing the knowledge and competences involved in digital literacy [27], [28].

Second, the designed application is named "Edsodia" or Edukasi Sosial Media (Social Media Education). The concept starts from student's purpose in using social media. The true social media is about sharing the right information, wise way of communication between people, also sharing experiences through photos and videos based on reality. This application is also designed to create a social forum among students in responding to a social phenomenon. In product analysis phase, the authors decide on which content will be presented on the application so that it can support learning process. The contents that will be presented in the application are: profile, social news, articles, video, images, forum, and explore. These are the application components that should be known: 1) Activity, where it shows a user interface (UI) to user; 2) Service, not having UI but runs as a background process; 3) Intens, a mechanism to draw an action in detail such as how to take photo; 4) Content providers, provides way to access data that is required for an activity, and 5) Resource, used to store noncoding files that are required in an application such as icon file, picture file, video file, etc [15].

Third, validation result from media expert shows an $80,33 \%$ average. Based on validation level category, this score means that it is very good to use mobile application in learning. Such statement is supported by a theory stated [29]. That media are the vehicle or physical tools that provides messages and stimulate students to learn. 
Schramm (1964) stated that media is a technology that carries information or instructional message. [30]. In other words, media is a learning resource component or physical vehicle that contains instructional materials in students' environment that is able to stimulate students to learn. Thus, media as one component of learning should be based on guidance to the students to make them realize the truth, virtues, and literacy through the process of considering the proper value and consistent actions as information society [31], [32].

\section{CONCLUSION}

Based on the discussion, the conclusions are drawn as follow:

1. This research and development is conducted with a design adapted from ADDIE development model that covers five phases, namely: analysis, design, development, implementation, and evaluation.

2. The designed application is named "Edsodia". The concept begins from student's purpose in using social media. The true social media is about sharing the right information, wise way of communication between people, also sharing experiences through photos and videos based on reality. This application is also designed to create a social forum among students in responding to a social phenomenon. The contents that will be presented in the application are: profile, social news, articles, video, images, forum, and explore.

3. Validation result from media expert shows an $80,33 \%$ average score. Based on validation level category, this score means that it is very good to use mobile application in learning.

\section{AUTHORS' CONTRIBUTIONS}

Aim Abdulkarim and Neiny Ratmaningsih contributed in analyzing the research results and providing critical insights into manuscript writing. Meanwhile, Pitria Sopianingsih and Diana Noor Anggraini are in charge of collecting data and writing research reports and article or manuscript. All authors reviewed manuscripts.

\section{REFERENCES}

[1] Tjandrawinata, R.R. Industri 4.0: Revolusi industri abad ini dan pengaruhnya pada bidang kesehatan dan bioteknologi. Jurnal Medicinus, Vol 29, Nomor 1, Edisi April. 2016.

[2] Oetomo, B. S. D. Perencanaan dan Pengembangan Sistem Informasi Edisi I. Yogyakarta: ANDI. 2002.

[3] Muntoha, dkk. Pengembangan sistem evaluasi pembelajaran berbasis web (web based learning assessment system). Jurnal Ilmiah Jurusan Fisika Kampus Unnes Sekaran Gunungpati. 195-199. (2010).
[4] Sakat, A. A., Mohd Zin, M. Z., Muhamad, R., Ahmad, A., Ahmad, N. A., \& Kamo, M. A. Educational Technology Media Method in Teaching and Learning Progress. American Journal of Applied Sciences , (2012). pp 874-888.

[5] Darling-Hammond, L., \& Bransford, J. Preparing Teachers for a Changing World: What Teachers should Learn and be able to do. San Francisco: Jossey-Bass. (2005).

[6] Georgiev, T., Georgieva, E., \& Smrikarov, A. MLearning : a New Stage of E-Learning. International Conference on Computer Systems and Technologies, 1-5. (2004).

[7] Triarso, A. Pengembangan Mobile Learning. (2010). Retrieved from: http://medukasi.com/pengembangan mobile edukasi.htm.

[8] Komalasari, K. Pembelajaran Kontekstual: Konsep dan Aplikasi. Bandung: Refika Aditama. (2010).

[9] Heinich et.al. Instructional Media and Technologies for Learning. New Jersey. Practice Hall. (2002)

[10] Sadiman, A. Media Pendidikan. Jakarta: Rajwali Press (2008)

[11] Ibrahim. H. Media Pembelajaran: Arti, fungis, landasan, penggunaan, klasifikasi, pemilihan, dan penulisan naskah slide. Malang. FKIP. (2001)

[12] Lubis, Isma. R, Solihah, M, Sugiyarto, K.H, Ikhsan, J. (2015). Pengembangan Media Mobile Learning "Chemondro" Berbasis Android Sebagai Suplemen Belajar Siswa SMA. Seminar Nasional Pendidikan Sains, Magister Pendidikan Sains dan Doktor Pendidikan IPA FKIP UNS, Surakarta, 19 November 2015.

[13] Sarrab, Mohamed, Laila Elgamel, \& Hamza Aldabbas. (2012). Mobile Learning (M-Learning) and Educational Environments. International Journal of Distributed and Parallel System, 3(4): 35. Tersedia http://www.airccse.org/journal/ijdps/papers/0712ij dps04.pdf [diakses 7- 11-2015].

[14] Prawiradilaga, Dewi Salma. (2012). Wawasan Teknologi Pendidikan. Jakarta: Prenada Media.Oktiana, G. D. Pengembangan media pembelajaran berbasis android Dalam bentuk buku saku digital untuk mata pelajaran Akuntansi kompetensi dasar membuat ikhtisar siklus Akuntansi perusahaan jasa di kelas XI MAN 1 Yogyakarta tahun ajaran 2014/2015. (2015). Retrieved fromhttps://eprints.uny.ac.id/21128/1/SKRIPSI\%2 OFULL\%20GIAN\%20DWI\%20\%2811403241023 $\% 29 . p d f$

[15] O'Malley,C, dkk. Guidelines For Learning/Teaching/Tutoring in a Mobile 
Environtment (2003). (Online), (http://www.mobilearn.org/download/results/guide lines.pdf

[16] Ally, M. Mobile learning: transforming the delivery of education and training. Edmonton: AU Press. (2009).

[17] Mehdipour, Yousef \& Hamideh Zerehkafi. Mobile Learning of Education: Benefeits and Challenges. International Journal of Computational Engineering Research, (2013). 3(6): 93. Tersedia di

http://www.ijceronline.com/papers/Vol3 issue6/pa rt\%203/P0363093010 0.pdf [diakses 7-11-2015].

[18] Mostakhdemin-hosseini, A., \& Mustajärvi, J. Framework for Mobile Learning System Based on Education Component. In Proceedings of the International Conference on Theory and Applications of Mathematics and Informatics (2003) (pp. 191-196). Alba Iulia.

[19] Bawden D (2008) Origins and concepts of digital literacy. In: Lankshear $\mathrm{C}$ and Knobel M (ed.) Digital Literacies: Concepts, Policies and Practices. New York: Peter Lang, 17-32.

[20] Fredericksen et al. The Undoing effect of positive emotion, 2000; 24, 237-258

[21] UNESCO. The Prague Declaration. "Towards an Information Literate Society.” (2003).

[22] Aoun, J.E. Robot-proof: higher education in the age of artificial intelligence. US: MIT Press. (2017).

[23] Trilling, B \& Fadel, C. 21st-century skills: learning for life in our times. US: Jossey-Bass A Wiley Imprint. (2009).
[24] Borg, W. R.,and Gall, M.D., Educational Research: An Introduction ( $\left.5^{\text {th }} \mathrm{ed}\right)$. New York: Longman. (1989).

[25] Fraenkel, Jack R. And Norman E. Wallen. How to Design and Evaluate in Research. New York: The McGraw-Hill Companies, Inc. (2006).

[26] Bogdan, R. C. \& Biklen, K. Sari. Qualitative Research for Education: An Introduction to Theory and Methods. Boston London: Allyn and Bacon, Inc. (1982).

[27] Goodfellow, RLiteracy, literacies, and the digital in higher education. Teaching in Higher Education, . (2011). 16(1) pp. 131-144.

[28] Irving, C. \& Crawford, J. A National Information Literacy Framework, Scotland: (2007) online at: http://www.caledonian.ac.uk/ils/framework.html

[29] Briggs. L. Principles of Constructional Design. New York. Holt, Rinehart and Winston. (1970).

[30] Schramm, W. Mass media and national development: The role of information in the developing countries (Vol. 25). Stanford, CA: Stanford University Press. (1964).

[31] Abdulkarim, A., Ratmaningsih, N., \& Anggraini, D. N. Developing Civicpedia as a Civic Education ELearning Media To Improve Students' Information Literacy. Journal of Social Studies Education Research, (2018). 9(3), 45-61.

[32] Komalasari, K \& Saripudin, DValue-Based Interactive Multimedia Development through Integrated Practice for the Formation of Students' Character. The Turkish Online Journal of Educational Technology, volume 16 issue 4, . (2017). p. 179-186. 